\title{
The Determinant of Financial Performance of Indian Public Sector Banks- A Panel Data Approach
}

\author{
Vikram Jeet ${ }^{1} \&$ Parvesh Kumar Aspal ${ }^{2}$ \\ ${ }^{1}$ University of Jeddah, College of Business, Department of Business Administration, Jeddah, Saudi Arabia \\ ${ }^{2}$ IKG Punjab Technical University, Jalandhar, Punjab, India \\ Correspondence: Vikram Jeet, University of Jeddah, College of Business, Department of Business Administration, \\ Jeddah, Saudi Arabia. E-mail: vjram@uj.edu.sa
}

Received: June 21, 2020

Accepted: August 12, 2020

Online Published: October 4, 2020

doi:10.5430/ijfr.v11n5p285

URL: https://doi.org/10.5430/ijfr.v11n5p285

\begin{abstract}
In the accelerated development of an economy, the role of a vibrant banking system and financial structure is considered as highly indispensable. The banking sector is recognized as an important element to portrait the financial and economic strength of a country. The economic importance of the banking system may be considered in the form of capital formation, inspiring innovation, monetization, and facilitator of monetary policy. The present research work investigates the association between banks' profitability and the banks' specific factors of Indian Public Sector Banks. The research work is based on secondary data drawn from annual reports of banks from the period of 2015 to 2019 . The panel data regression statistical technique has been employed to vindicate the influence of explanatory variables viz. Capital Adequacy, Human Capital, Liquidity, Management Efficiency, Asset Quality, and Earning Quality, which have been employed as independent variables and Return on Equity, as the dependent variable. Panel data regression model results have reported that the regression coefficients are found statistically significant and the high value of adjusted R- square expresses the overall best fit of the fixed effects model. A significant positive relationship has been found between the financial performance of bank (ROE) and human capital, liquidity, management efficiency, and asset quality. Whereas capital adequacy and earning quality of the banks have an insignificant impact on the profitability of banks. Hence, the financial performance evaluation enables the banks to analyze their financial strength and to follow necessary protective initiatives for its sustainability.
\end{abstract}

Keywords: return on equity, capital adequacy, human capital, liquidity, management efficiency, asset quality, earning quality

\section{Introduction}

Sustainable growth of a nation depends upon several factors, in which the role of the financial system is highly important, especially in developing countries. India is a developing country and acknowledges as the fastest growing economy (Economic survey of India 2018-19). The banking sector is termed as a lifeline of an economy and its people (Shabani et al 2019; Mohapatra \& Jha, 2018). In this way, the efficient banking sector classified as a prerequisite in the emergent of the important economic and social sectors in the country and pushed the economy towards the new horizons of developed economies (Debnath \& Shankar 2008; Dhawan \& Aspal 2014; Koley 2019).

Banking and financial institutions are considered as the network of personal savings and distributions of micro and macro credits, contributing to the implementation of economic planning and government financial policies (Ariccia \& Marquez, 2004). In addition to this, it serves the important function of relocating and stimulates the funds into different investment options (King \& Levine, 1993). The financial sector enables financial operations by mobilizing deposits to the economic activities, which accompanying to "stimulates a country's economic growth by allocating financial resources into suitable financial demand" (Levine, 2005). The role banking sector in stabilizing the prices and generating employment is highly recognized (Mistry \& Savani, 2015). The banking and financial sector facilitated by the growth of the different economic sectors by playing a leading role in transforming their growth and development. Furthermore, it facilitates an economy to organize and circulate the required funds to the different government and non-government economic initiations for rapid growth in the economy (Ebong 2005; Patrick 1996). 
The Indian banking sector has noticed a significant rise and expansion after the liberalization policy all through supporting the other major industries. The role of the efficient banking system at the micro and macro level can be recognized (Al-Homaidi et al. 2018). In the highly competitive market, banks strive its functioning to earn more profits to survive and the profitable banking sector helps the economy to absorb the global financial crises and provide stability in the system. It reflects a brighter and glorious side of the financial sector, but the recent emerged cases of the financial crisis and bank defaulter in India, also confirmed the question mark on the banks' performance at national as well as at international levels. It creates a situation to think and there is an urgent need to supervise and understand the performance of the financial institutions, as it significantly influences the country's economy (Barth et al. 2006).

\section{Review of Literature}

Numerous academician, research professionals, economists and policymakers have investigated and analyzed the performance and profitability of banks around the globe (Abba, et al, 2018; Klaassen \& Eeghen 2014; Kosmidou et al., 2005; Kosak \& Cok, 2008; Akhavein, Berger, \& Humphery, 1997; Athanasoglou et al., 2006). The financial performance indicators such as ROA, CAR, and the equity-to-asset ratio has a great influence and significant role in the banks' profitability (Klaassen \& Eeghen 2014; Abba et al. 2018). The growth rate of GDP, rate of unemployability of a country, and the profitability of banks move congruently (Tan \& Floros, 2012). It has also been observed that the wider span of branches network and size of the bank in term of net worth, influence the performance and profitability (Akhavein, et al, 1997; Sufian \& Habibullah, 2009; Zardkoohi \& Kolari, 1994; Kosak \& Cok, 2008).

To understand the complexity of the banks' performance, and its importance, researchers have developed different scientific models and techniques, through which the performance of banks can be analyzed. The CAMEL methodology is a highly preferable and effective technique to analyze the banks' Performance (Aspal \& Malhotra, 2013; Al-Tamimi, 2010; Dhawan \& Aspal, 2014; Aburime, 2008; Mishra \& Aspal, 2013; Chantapong, 2005; Veni (2004). Karri, et al. (2015) applied the concepts of the CAMEL model ("Capital Adequacy, Asset Quality, Management Efficiency, Earning Ability and Liquidity") to examine Indian banks' performance. Saif, et al. (2017) examined the impression of the CAMEL model on the NIM, ROE, and ROA of the banks. Nagarkar (2015), implemented the principle component analysis technique to explore the banks' performance in India. Likewise, in numerous studies, ROA and ROE of the banks are the true representation of the banks' financial strength (Sporta, 2018). The financial determinants such as; Board Size and corporate governance, Bezawada, (2020); risk management, (Bastom et al. 2017); operational efficiency; asset utilization; asset size (Mistry \& Savani, 2015) and size of the bank (Ngware et al. 2020), can be useful parameters for examining the bank's financial stability and profitability.

Along with the banks' specific factors, the researcher has also taken the macroeconomic factor to analyze its impact on the profitability such as; demonetization (Almaqtari et al. 2018); inflation rate, oil price, market capitalization and rate of GDP rate, (Robin et al. 2018); (Chowdhury \& Rasid. 2017); competitive market and economy growth (Petria et al. 2015); the rate of interest and rate of tax (Dietrich \& Wanzenried, 2011); Inflation Rate and Financial Crisis, (Bouzgarrou et al. 2017); GDP and Inflation, (Tan, 2016); political factors, (Yahya et al. 2017) inflation and unemployment (Singh \& Sharma 2016). Majumder \& Rahman (2016) implemented the CAMEL technique to analyze the financial stability in Bangladesh's banking system. Similarly, many researchers evaluated banks' profitability worldwide such as; How et al., (2005); Shaari \& Fadhilah, (2001); AbdusSamad \& Hassan, (1999) on the Malaysian banking industry; Tan \& Floros (2012) on the banks in China; Seref (1995) on the Bahrain Islamic Bank; Zardkoohi, A., \& Kolari, J. (1994) on the banks of Finland; Bashir (2003) on the Middle Eastern countries; Naceur \& Goaied (2001) on the Banks in Tunisia; Sporta, (2018) \& Ngware et al. (2020) on banks of Kenya; Saif et al. (2017) on Saudi Arabian banks; and Balaji \& Kumar (2016) on Indian Banking system.

\subsection{Objectives and Rationale of the Study}

On reviewing the literature and based on above discussions, the prime objective of the present study is to analyze the effects of banks' specific factors on the financial performance in Indian Public Sector Banks. The volatile market situations of the country influenced the banking industry most, as the Indian public sector banks faced a lot of challenges in the last five year, in from of increase NPAs and other fiscal issues. Findings from different research papers provide a mixed result and we observe that many of the studies are confirmatory studies in different countries and different time frames. In Indian context, less literature was observed linking the major deterrents to bank profitability in a wider time frame. Thus, in the recent period there is a need to analysis the banks' profitability and its determinants. Hence, an analysis to ascertain the influence bank specific factors focused on the Capital Adequacy, Human Capital, Liquidity, Management Efficiency, Asset Quality, and Earning Quality on the profitability of Indian public sector banks with the balanced panel data results for the period 2015-2019 has been undertaken. 


\section{Research Methodology}

\subsection{Data Collection}

To attain the above objective, the financial data for the year 2015 to the year 2019 of public sector banks, published in the annual reports, has been used as the secondary data. For the present study, 19 Indian banks have been selected as a sample. All banks chosen as the sample in research are the public sector banks "Allahabad Bank, Andhra Bank, Bank of Baroda, Bank of India, Bank of Maharashtra, Canara Bank, Central Bank Of India, Corporation Bank, Dena Bank, Indian Bank, Indian Overseas Bank, Oriental Bank of Commerce, Punjab And Sind Bank, Punjab National Bank, Syndicate Bank, UCO Bank, Union Bank of India, United Bank of India and Vijaya Bank".

\subsection{Research Design}

The foremost purpose of every commercial bank is to generate and maximize revenues. In pursuing the prime objective, the banks follow different strategies and perform a wide variety of activities. These commercial activities are the source of revenues for the bank and have an impact on the bank's performance. So, the present research work is undertaken to analyze the relationship between the banks' specific factors and the Indian Public Sector Banks' financial performance.

\subsection{Model Specification}

To explore the current study, banks' profitability is taken as the dependent variable for assessing its relationship with banks' specific variables. The banks' specific explanatory variables include "Capital Adequacy", "Human Capital", "Liquidity", "Management Efficiency", "Asset Quality", and "Earning Quality", which have been employed as independent variables.

\subsubsection{Bank Performance Indicator}

Numerous researchers have used various financial ratios to examine the commercial banks' profitability, of which "Return on Equity" (ROE) is the prominent ratio (Flamini \& Schumacher, 2009; Al-Tamimi, 2008; Beck, et al., 2005; Murthy \& Sree, 2003; Berger, 1995). ROE represents the relationship between profit earned by the bank and the sum of shareholders' equity. In other words, it represents the expectations of shareholders in return for their investment. It means a high ratio of "Return on equity" represents the high returns on investment and generates maximum profits and termed as the better organization Khrawish (2011). Numerous research scholars have applied ROE as a gauge to measure financial performance (Bagchi and Khamrui, 2012; Beneda, 2009; Brigham and Daves, 2007; San and Heng, 2011).

\subsubsection{Independent Variable Description and Hypothesis}

In numerous empirical research studies, various researchers have opined that profitability influences the bank's growth and survival. The independent variables generally determine the profitability of banks. (Al-Tamimi, 2010; Aburime, 2009; Flamini et al., 2009) In the present study, the following ratios have employed as independent variables. "Capital Adequacy" is the first independent variable, represents the loss bearing capacity of the banks. To provide the safety against the losses, RBI has imposed the guideline to maintain the CAR of $9 \%$. Higher the ratio means more security for the investments and represents the financial well-being of the organization. The second independent variable of the study chosen as "Human Capital" represented the total cost and expenses incurred on the employees. The employees are value creator and should be acknowledged as the capital as other physical and financial capital resources (Pulic, 2008). Thus, in the modernized business model, the expenses incurred on the workforce not considered as the cost, rather it assumed as the investment on the employees for the business development. The ratio of the total wages to total is applied to measure human capital. The third variable of the study is the "Liquidity", another factor which determines the bank's financial performance. It represents the financial ability to transform their current assets into liquid assets to fulfill the cash flow requirements and credit demands. A fourth important variable to analyze the financial performance is "Management Efficiency". It represents the administrative capabilities and competencies of the bank's administration regarding strategic implementation and responsiveness towards the dynamic environment. The fifth independent variable of the study chosen as "Asset Quality", which represents the financial strength of the banks. "Quality of earning" is also an independent variable used in the present study that highlights the revenues earned from lending business. For achieving the objective of the study, the hypotheses have been tested:

$\mathrm{H}_{1 \mathrm{~A}}$ : "Capital Adequacy has a significant influence on the banks' profitability".

$\mathrm{H}_{2 \mathrm{~A}}$ : "Human Capital has a significant influence on the banks' profitability".

$\mathrm{H}_{3 \mathrm{~A}}$ : "Liquidity has a significant influence on the banks' profitability". 
$\mathrm{H}_{4 \mathrm{~A}}$ : "Management Efficiency has a significant influence on the banks' profitability".

$\mathrm{H}_{5 \mathrm{~A}}$ : "Asset Quality has a significant influence on banks' profitability"

$\mathrm{H}_{6 \mathrm{~A}}$ : "Earning Quality has a significant influence on the banks' profitability".

Table 1. Selected variable's description for the study

\begin{tabular}{lll}
\hline Variables & Description & Notation \\
\hline $\begin{array}{l}\text { Dependent Variable } \\
\text { Return on Equity } \\
\text { Independent Variable }\end{array}$ & Profits after tax and Preference dividends/ net worth & ROE \\
Capital Adequacy & Capital Adequacy Ratio & CAR \\
Human Capital & Ratio of Wages to Total Income & HC \\
Liquidity & Ratio of Deposits to Total Liability & LQ \\
Management Efficiency & Ratio of Demand and Savings Bank deposits to Total Deposits & ME \\
Asset Quality & Ratio of Net NPA to Net Advances & AQ \\
Earning Quality & Cost of Borrowing Ratio & EQ \\
\hline
\end{tabular}

\subsubsection{Econometric Specification}

The panel data regression equations have been estimated to explore the influence of the bank's specific factors on return on equity.

$$
\mathrm{ROE}_{\text {it }}=\alpha_{0}+\beta_{1} \mathrm{CAR}_{\mathrm{it}}+\beta_{2} \mathrm{HC}_{\mathrm{it}}+\beta_{3} \mathrm{LQ}_{\mathrm{it}}+\beta_{4} \mathrm{ME}_{\mathrm{it}}+\beta_{5} \mathrm{AQ}_{\mathrm{it}}+\beta_{6} \mathrm{EQ}_{\mathrm{it}}+\mathrm{e}_{\mathrm{it}}
$$

Where:

$\mathrm{ROE}_{\mathrm{it}}=$ Financial Performance indicator of bank $i$ at time $t$

$\alpha_{0}=$ Intercept term

$\mathrm{CAR}_{\mathrm{it}}=$ Capital Adequacy of bank $i$ at time $t$

$\mathrm{HC}_{\mathrm{it}}=$ Human Capital of bank $i$ at time $t$

$\mathrm{LQ}_{\mathrm{it}}=$ Liquidity of Bank $i$ at time $t$

$\mathrm{ME}_{\mathrm{it}}=$ Management Efficiency of Bank $i$ at time $t$

$\mathrm{AQ}_{\mathrm{it}}=$ Asset Quality of bank $i$ at time $t$

$\mathrm{EQ}_{\mathrm{it}}=$ Earning Quality of Bank $i$ at time $t$

$\mathrm{e}_{\mathrm{it}}=$ Stochastic error term

\section{Data Interpretation}

In the above equation "Panel Data Regression Model" has been applied, in which the impact of the different factors analyzed on the dependent variable. The validity of various regression assumptions and specification tests for regressions models has also been analyzed. In the second step, the regression analysis has been estimated "Fixed Effects Model", "Random Effects Model" and "Pooled Ordinary Least Squares". These three assessment models get compared to obtain the best fit model using the two specification tests such as the "Hausman Test" and the "Redundant Fixed Effect Test".

\subsection{Diagnostic Tests}

The various fundamental regression assumptions have been satisfied to validate the regression model. A series of analytical tests are also applied to check the presence of the Normality of data, Multicollinearity, Homoscedasticity, Autocorrelation, and Stationarity in the regression models which may influence the efficacy of the estimators.

\subsubsection{Testing of Normality}

The normality test has been assessed for the data, which is the prime fundamental assumption for many statistical tests. It is the primitive requirement that data must have the characteristic of normal distribution. In the present study, the 
value of the "Jarque-Bera Test" observed as 3.460 with a p-value of 0.177 , which signifies that data is normally distributed.

\subsubsection{Multicollinearity Test}

The multicollinearity test has applied to analyze the correlation and multicollinearity of the independent variables. It is suggested that the independent variables must satisfy the conditions of no high correlation and no multicollinearity for better results. The "Pearson correlation coefficient matrix" and the "Variance Inflation Factor" (VIF) have been analyzed to prove the statement. "The closer the value of VIF of one, the lesser will be the degree of multicollinearity and vice-versa" (Gujarati, 1995).

The calculated VIF values presented in table 2. All the calculated values observed less than 10, which are under the accepted parameter (Gujarati, 1995), and the average VIF value is calculated as 1.65, which signified the no multicollinearity.

Table 2. Multicollinearity test for all independent variables ("Variance Inflation Factor")

\begin{tabular}{lc}
\hline Variable & Variance Inflation Factor \\
\hline Capital Adequacy & 1.24 \\
Human Capital & 1.76 \\
Liquidity & 1.62 \\
Management Efficiency & 1.80 \\
Asset Quality & 1.59 \\
Earning Quality & 1.92 \\
\hline
\end{tabular}

The average value of the VIF score is 1.65 , which represents that the problem of multicollinearity has not been found among independent variables. Moreover, Table 3 depicts that the Pearson correlation coefficients between independent $\&$ dependent variables have been found lower than the standard. So, the above correlation matrix highlights that the multicollinearity problem is ruled out.

Table 3. Correlation matrix

\begin{tabular}{llllllll}
\hline & ROE & CAR & EQ & HC & LQ & ME & AQ \\
\hline ROE & 1.000 & 0.172 & -0.270 & 0.073 & -0.286 & 0.156 & 0.025 \\
CAR & 0.172 & 1.000 & -0.311 & -0.339 & -0.278 & -0.143 & -0.294 \\
EQ & -0.270 & -0.311 & 1.000 & 0.397 & 0.602 & 0.164 & 0.370 \\
HC & 0.073 & -0.339 & 0.397 & 1.000 & 0.258 & 0.550 & 0.373 \\
LQ & -0.286 & -0.278 & 0.602 & 0.258 & 1.000 & 0.034 & 0.143 \\
ME & 0.156 & -0.143 & 0.164 & 0.550 & 0.034 & 1.000 & 0.512 \\
AQ & 0.025 & -0.294 & 0.370 & 0.373 & 0.143 & 0.512 & 1.000 \\
\hline
\end{tabular}

\subsubsection{Testing of Homoscedasticity}

Another assumption underlying multiple regression analyses that must be satisfied with the regression model to be valid is Homoscedasticity. During the analysis, it has been found that the Chi-Square (p-value 0.6598), which is more than 0.05 , statistically proves that there is not the problem of Heteroscedasticity in the data and data is Homoscedastic.

\subsubsection{Testing of Autocorrelation}

Auto Correlation testing (Durbin-Watson Statistic) has also been tested in the study. It has been observed by the many researchers that the variable must be tested for the autocorrelation, and accepted values must be between 1.4 to 2.6. In the present study, statistic value 1.90 is calculated from the given test, which approves the conditions of autocorrelation and satisfies the standard rules of acceptance given by Luo and Nichols (2003). Hence, there is no autocorrelation among the variables has been found during the study. 


\subsubsection{Testing of Stationarity}

In the present study, the test of stationarity has also the major concern, as in time series data there is the problem of Non-stationary exist, which does not provide the authenticity in the results. To check data free from Non-stationary "Augmented Dickey-Fuller Test" has been tested and presented in table 4, which signifies that data is stationary. All the calculated values found significant.

Table 4. Test of stationarity

\begin{tabular}{ccc}
\hline Variables & t-Statistic & p-value \\
\hline ROE & -3.581236 & $0.008^{*}$ \\
CAR & 8.076479 & $0.000^{*}$ \\
HC & -6.526719 & $0.000^{*}$ \\
LQ & -5.785279 & $0.000^{*}$ \\
ME & -3.887540 & $0.003^{*}$ \\
AQ & -3.435038 & $0.012^{*}$ \\
EQ & -5.549823 & $0.000^{*}$ \\
\hline
\end{tabular}

* Significant at $5 \%$ level of significance

\subsection{Specification Tests for Regression Model}

The specification tests for all related regressions models have been applied to verify and select the appropriate regression model.

\subsubsection{Redundant Fixed Effect Test}

In the present study, the "Redundant Fixed Effect Test" has been employed to select an appropriate model between Panel data regression and Pooled OLS regression. For this purpose, cross-section, period effects, and total effects have been checked. The assumption of the test states the redundant effects of the variables. The statistical value highlights the acceptance of the panel data regression model over the pooled OLS model. Regarding ROE, the financial performance indicator, the $\chi^{2}$ value $10.433(\mathrm{p}$-value $=0.000)$ reflects the rejection of the null hypothesis.

\subsubsection{Hausman Test}

The purpose of applying the "Hausman Specification Test" is to select an appropriate model between the fixed effect model and the random effect model. In the case-independent variable (ROE), the result has confirmed the rejection of the null hypothesis $\left(\chi^{2}=53.252\right.$, p-value $\left.=0.000\right)$. Consequently, the fixed effect model has been selected as compared to the random effect model.

\subsection{Panel Data Regression Model Analysis}

From the above specification tests, it has been found that the fixed effect model is more appropriate and best fit for the regression analyses. The calculated findings of regression analyses revealing the relationships among the variables presented in the following Table 5. 
Table 5. Panel data analysis results

\begin{tabular}{|c|c|c|c|c|c|c|c|c|c|}
\hline \multirow[t]{2}{*}{ Independent Variable } & \multicolumn{3}{|c|}{ Pooled OLS } & \multicolumn{3}{|c|}{ Panel (FEM) } & \multicolumn{3}{|c|}{ Panel (REM) } \\
\hline & Coeff. & t-Stat. & Prob. & Coeff. & t-Stat. & Prob. & Coeff. & t-Stat. & Prob. \\
\hline CAR & 0.0832 & 1.3654 & 0.1756 & 0.0231 & 0.5171 & 0.6067 & 0.0479 & 1.1579 & 0.2500 \\
\hline Human Capital & 0.0557 & 1.4655 & 0.1463 & 0.0555 & 1.8625 & $0.0667 * *$ & 0.0520 & 1.9209 & 0.0580 \\
\hline Liquidity & 0.0592 & 1.3053 & 0.1952 & 0.0569 & 1.8071 & $0.0750 * *$ & 0.0179 & 0.6027 & 0.5482 \\
\hline $\begin{array}{l}\text { Management } \\
\text { Efficiency }\end{array}$ & 0.0096 & 0.6410 & 0.5232 & 0.0485 & 2.9922 & $0.0038^{*}$ & 0.0279 & 2.1872 & 0.0314 \\
\hline Asset Quality & 0.0189 & 0.5487 & 0.5846 & 0.0628 & 2.3850 & $0.0198^{*}$ & 0.0518 & 2.1579 & 0.0337 \\
\hline Earning Quality & 0.0885 & -1.7845 & 0.0778 & -0.0023 & -0.0639 & 0.9492 & -0.0553 & -1.6323 & 0.1062 \\
\hline Observations & & 95 & & & 95 & & & 95 & \\
\hline R-squared & & 0.1657 & & & 0.7734 & & & 0.2198 & \\
\hline Adjusted R-squared & & 0.1089 & & & 0.6958 & & & 0.1666 & \\
\hline F-statistic & & 2.9146 & & & 9.9595 & & & 4.1324 & \\
\hline Prob. (F-statistic) & & 0.0122 & & & $0.0000^{*}$ & & & 0.0010 & \\
\hline \multicolumn{10}{|c|}{ Redundant Fixed Effect Test } \\
\hline Chi-Square Statistic & & & & & 10.4331 & & & & \\
\hline Prob. & & & & & 0.000 & & & & \\
\hline \multicolumn{10}{|c|}{ Hausman Test } \\
\hline Chi-Sq. Statistic & & & & & 53.2525 & & & & \\
\hline Prob. & & & & & 0.000 & & & & \\
\hline
\end{tabular}

* Significant at $5 \%$ level of significance

** Significant at $10 \%$ level of significance

The statistical values of all regression models are depicted in table 5, have revealed that the regression coefficients of the FEM model are reported statistically significant. The banks' specific factors like; human capital, liquidity, asset quality, and management efficiency are found a significant and positive relationship with the performance (ROE). Whereas the other two determinants such as capital adequacy and earning quality insignificantly influenced the profitability. The results of the present study are supported by the finding of Sporta, (2018), also found a negative influence of capital adequacy on the performance of banks. The results of the present study are conflicting in the study of Iranian Banks, suggested that the CAR ratio bears a positive effect on the performance (Bateni, et al. 2014). The high value of adjusted R2 (69.58) expresses the overall best fit of the model, which is further substantiated by F-statistics $(p=0.0000)$, is statistically significant. The finding of the present research work is in concurrence with the earlier research investigations. Like, the results supported by the findings of Kosmidou (2008). It has been observed that the banks' profitability (ROE) significantly influenced by human capital. Similarly, the liquidity of the banks has also shown a positive effect on the banks' profitability. The results found consistent with the observations of Ongore \& Kusa (2013), which found liquidity has a significant effect on and banks' performance. Besides, management efficiency demonstrated a positive effect on banks' profitability (ROE). The results have been also found consistent with the observations of Ongore \& Kusa (2013), who also highlighted significant effects of management efficiency on the banks' financial wellbeing. Further, the influence of the banks' asset quality on maintaining financial strength is found statistically significant. The similar results also highlighted by Flamini, et al. (2009), in which the observations between the assets quality and financial performance observed positively associated. On the other side results of the study opposed the finding of Berger (1995), where the effects of banks' asset quality on performance observed statistically insignificant. Surprisingly, the earing quality of the banks with the return of equity is found insignificant.

\section{Results Summary}

For the attainment of objectives, hypotheses with the predicted assumption of having an influence of banks' specific determinants on the banks' financial performance have been formulated. In Table 6, the results summary of the hypotheses tested has been presented. 
Table 6. Results of the tested hypotheses

\begin{tabular}{llcl}
\hline Hypotheses & Description & p-values & Result \\
\hline \multirow{2}{*}{$\mathrm{H}_{1 \mathrm{~A}}$} & "Capital Adequacy has a significant influence on & $\mathbf{0 . 5 1 7 1}$ & \multirow{2}{*}{ Not Supported } \\
& banks' profitability" & $(0.6067)$ & \\
$\mathrm{H}_{2 \mathrm{~A}}$ & "Human Capital has a significant influence on & $\mathbf{1 . 8 6 2 5}$ & Supported \\
& banks' profitability" & $(0.0667)$ & \\
$\mathrm{H}_{3 \mathrm{~A}}$ & "Liquidity has a significant influence on banks' & $\mathbf{1 . 8 0 7 1}$ & Supported \\
& profitability" & $(0.0750)$ & \\
$\mathrm{H}_{4 \mathrm{~A}}$ & "Management Efficiency has a significant & $\mathbf{2 . 9 9 2 2}$ & Supported \\
& influence on banks' profitability" & $(0.0038)$ & \\
$\mathrm{H}_{5 \mathrm{~A}}$ & "Asset Quality has a significant influence on & $\mathbf{2 . 3 8 5 0}$ & \multirow{2}{*}{ Supported } \\
& banks' profitability" & $(0.0198)$ & \\
$\mathrm{H}_{6 \mathrm{~A}}$ & "Earning Quality has a significant influence on & $\mathbf{- 0 . 0 6 3 9}$ & \multirow{2}{*}{ Not Supported } \\
& banks' profitability" & $(0.9492)$ & \\
\hline
\end{tabular}

In the above Table 6, the regression coefficients of the relationship between the banks' financial performance (ROE) with management efficiency, liquidity, human capital, and asset quality are found statistically significant. Thus, the hypotheses $\mathrm{H}_{2 \mathrm{~A}}, \mathrm{H}_{3 \mathrm{~A}}, \mathrm{H}_{4 \mathrm{~A}}$, and $\mathrm{H}_{5 \mathrm{~A}}$ are accepted. Whereas regression coefficients of capital adequacy and earning quality is found insignificant with the banks' financial performance. Hence, the hypothesis $\mathrm{H}_{1 \mathrm{~A}}$ and $\mathrm{H}_{6 \mathrm{~A}}$ have been rejected. It implies that the determinants such as management efficiency, human capital, asset quality and liquidity help to maintain and increases the profitability of the banks in India. But, on the contrary, the capital adequacy and earning quality insignificantly influenced banks' financial performance.

\section{Conclusion}

The primary function of the banks is the allocating and utilizing of financial resources of an economy for the collective growth of a nation. Thus, the banks' financial performance can be an efficient mechanism to analyze the financial strength of a country. The present research works have been initiated to examine the banks' financial performance by focusing on the influence of specific determinants such as capital adequacy, human capital, liquidity, management efficiency, asset quality, and earnings quality. The finding revealed that the banks' profitability influenced by human capital, liquidity, management efficiency, and asset quality. Whereas the capital adequacy and earning quality does not affect the profitability of sample banks. The results are supported by the finding of Kosmidou (2008). Capital adequacy has found to have an insignificant influence on profitability, which has been found contrary to the finding of Berger (1995), where capital adequacy has a positive impact on the banks' profitability. It is observed that the banks that follow the humanistic approach gain the financial growth and development of their employees. In the study, human capital reported a significant influence on banks' portability. As far as, liquidity of the banks is concerned, the higher the liquidity expresses good financial strength (Rudolf, 2009). On the other hand, banks' liquidity significantly influenced the profitability. Management efficiency considered as the major determinant to ensure the profitability and survival of the bank. In the study, it has been evident from the results that the management efficiency of banks significantly influenced the banks' profitability. whereas the banks' asset quality which a crucial determinant of financial performance which signifies the banks' effectiveness of evaluation, monitoring, and collection of loans. The results highlighted the significant effects of banks' asset quality on profitability. On the contrary, insignificant influence is observed between the earning quality factor of performance measurement and the banks' profitability. On the bases above discussed inferences, most of the banks' internal component is the significant determinant for the banks' profitability. The results of the present study in concurrence and supported by many studies as discussed above. Hence, the periodical financial performance scanning facilitates the banks to analyze the financial strength and to take precautionary measures for sustainable. So, far as macroeconomic variables concern viz. GDP and inflation, it has an impact on the banks' performance, which cannot be ignored. It gives the further scope for the study, to include all micro and microeconomic factors to examine its influence on Indian commercial banks.

\section{References}

Abba, G., Okwa, E., Soje, B., \& Alkpitanyl, L. N. (2018). Determinants of capital adequacy ratio of deposit money banks in Nigeria. Journal of Accounting and Marketing, 7, 2. https://doi.org/10.4172/2168-9601.1000271 
Abdus, S., \& Hassan, M. K. (1999). The Performance of Malaysian Islamic Bank during 1984-1997: An Exploratory Study. International Journal of Islamic Financial Services, 1(3), 1-14. https://doi.org/10.2139/ssrn.3263331

Aburime, T. U. (2009). Determinants of Bank Profitability: Macroeconomic Evidence from Nigeria. International Economics and Finance Journal, 4(1-2), 69-91. Retrieved from https://www.researchgate.net/publication/228282854

Akhavein, J. D., Berger, A., \& Humphery, D. (1997). The effect of megamergers on efficiency and prices: Evidence from a bank profit function. Review of Industrial Organization, 12(1), 95-139. https://doi.org/10.1023/A:1007760924829

Almaqtari, F. A., Al-Homaidi, E. A., Tabash, M. I., \& Farhan, N. H. (2018). The determinants of profitability of Indian commercial banks: A panel data approach. International Journal of Finance \& Economics, 1-18. https://doi.org/10.1002/ijfe.1655

Al-Tamimi, H. A. (2010). Factors Influencing Performance of UAE Islamic and National Conventional Bank. Global Journal of Business Research, 4(2), 1-7.

Ariccia, Dell' G., \& Marquez, R. (2004). Information and Bank Credit Allocation, Journal of Financial Economics, 72(1), 185-214. https://doi.org/10.1016/S0304-405X(03)00210-1

Aspal, P. K., \& Malhotra, N. (2013). Performance Appraisal of Indian Public Sector Banks. World Journal of Social Sciences, 3(3), 71-88.

Athansasoglou, P., Brissimis, S., \& Delis, M. (2005). Bank-Specific, Industry-Specific and Macroeconomic Determinants of Bank Profitability. Bank of Greece Working Paper, (25), 5-26.

Balaji, C., \& Kumar, G. P. (2016). A Comparative Study on Financial Performance of Selected Public \& Private Sector Banks in India. Journal of Commerce and Trade, 11(2), 89-96.

Barth, J. R., Caprio, G. J., \& Levine, R. (2006). Rethinking Bank Regulation: Till Angels Govern. New York: Cambridge University Press.

Bashir, A. H. (2003). Determinants of Profitability in Islamic Banks: Some Evidence from the Middle East. Islamic Economic Studies, 11(1), 31-57.

Bastomi, M., Salim, U., \& Aisjah, S. (2017). The role of corporate governance and risk management on banking financial performance in Indonesia. Jurnal Keuangan dan Perbankan, 21(4), 670-680.

Bateni, L., Vakilifard, H., \& Asghari, F. (2014). The influential factors on capital adequacy ratio in Iranian banks. International Journal of Economics and Finance, 6(11), 108-116.

Berger, A. N. (1995). Problem loans and cost efficiency in commercial banks (Vol. 95, No. 5). Office of the Comptroller of the Currency.

Bezawada, B. (2020). Corporate Governance Practices and Bank Performance: Evidence from Indian Banks. Indian Journal of Finance and Banking, 4(1), 33-41.

Bouzgarrou, H., Jouida, S., \& Louhichi, W. (2017). Bank profitability during and before the financial crisis: Domestic vs. foreign banks. Research in International Business and Finance. https://doi.org/10.1016/j.ribaf.2017.05.011

Chantapong, S. (2005). Comparative Study of Domestic and Foreign Bank Performance in Thailand: The Regression Analysis. Economic Change and Restructuring, 38(1), 63-83.

Chowdhury, M. A. F., \& Rasid, M. E. S. M. (2017). Determinants of performance of Islamic banks in GCC countries: Dynamic GMM approach. Advances in Islamic Finance, Marketing, and Management, 49-80.

Debnath, R. M., \& Shankar, R. (2008). Measuring performance of Indian banks: an application data envelopment analysis. International Journal of Business Performance Management, 10(1), 57-85.

Dhawan, S., \& Aspal, P. K. (2014). Financial Performance Assessment of Banking Sector in India: A Case Study of Old Private Sector Banks. The Business \& Management Review, 5(3), 196-211.

Dietrich, A., \& Wanzenried, G. (2011). Determinants of bank profitability before and during the crisis: Evidence from Switzerland. Journal of International Financial Markets, Institutions \& Money, 21(3), 307-327. https://doi.org/10.1016/j.intfin.2010.11.002

Ebong, B. B. (2005). The banking industry and the Nigerian economy post-consolidation. Union Digest, 9(3), 17-30. 
Eissa, A., Al-Homaidi, M., Tabash, I., Najib, H., Farhan, S., \& Faozi, A. A. (2018). Bank-specific and macro-economic determinants of profitability of Indian commercial banks: A panel data approach. Cogent Economics \& Finance, 6, 1. https://doi.org/10.1080/23322039.2018.1548072

Flamini, V., Schumacher, M. L., \& McDonald, M. C. A. (2009). The determinants of commercial bank profitability in Sub-Saharan Africa (No. 9-15). International Monetary Fund.

How, J. C., Melina, A. K., \& Verhoeven, P. (2005). Islamic Financing and Bank Risks: The Case of Malaysia. Thunderbird International Business Review, 47(1), 75-94. https://doi.org/10.1002/tie.20041

India Brand Equity Foundation (IBEF). (2020). Indian Banking Industry Analysis. New Delhi: India Brand Equity Foundation.

Karri, H. K. et al. . (2015). A Comparative Study on Financial Performance of Public Sector Banks in India: An Analysis of CAMEL Model. Munich Personal RePEc Archive, Paper no. 62844. Retrieved from https://mpra.ub.unimuenchen.de/62844/

King, R. G., \& Levine, R. (1993). Finance and Growth: Schumpeter Might Be Right. Quarterly Journal of Economics, $108,717-737$.

Klaassen, P., \& van Eeghen, I. (2014). Analyzing bank performance: Linking ROE, ROA, and ROROC. SSRN. https://doi.org/10.2139/ssrn.2389443

Koley, J. (2019). Analysis of Financial Position and Performance of Public and Private Sector Banks in India: A Comparative Study on SBI and HDFC Bank. NSOU-Open Journal.

Kosak, M., \& Cok, M. (2008). Ownership structure and profitability of the banking sector: Evidence from the SEE-6 region. Journal of Economics and Business, 26(1), 93-122. Retrieved from https://hrcak.srce.hr/24485

Kosmidou, K. (2008). The Determinants of Banks' Profits in Greece during the Period of EU Financial Integration. Managerial Finance, 34(3), 146-159. https://doi.org/10.1108/03074350810848036

Levine, R. (2005). Finance and Growth: Theory, Evidence, and Mechanisms. Elsevier, North-Holland.

Majumder, T. H., \& Rahman, M. M. (2016). A CAMEL Model Analysis of Selected Banks in Bangladesh. International Journal of Business and Technopreneurship, 6(2), 233-266.

Mishra, S. K., \& Aspal, P. K. (2013). A CAMEL Model Analysis of State Bank Group. World Journal of Social Sciences, 3(3), 71-88.

Mistry, D. S., \& Savani, V. (2015). A Comparative Study of the Profitability Performance in the Banking Sector: Evidence from Indian Private Sector Bank. XVI Annual Conference Proceedings, 346-360.

Mohapatra, A. K., \& Jha, S. (2018). Bank Recapitalization in India: A Critique of Public Policy Concerns. FIIB Business Review, 7(1), 10-15.

Naceur, Ben S., \& Goaied, M. (2001). The determinants of the Tunisian Deposit Banks' Performance. Applied Financial Economics, 11, 317-319.

Nagarkar, J. J. (2015). Analysis of Financial Performance of Banks in India. Annual Research Journal of Symbiosis Centre for Management Studies, Pune, 3, 26-37.

Ngware, S. G., Olweny, T., \& Muturi, W. (2020). Do Bank Size Moderate Relationship between Banks’ Portfolio Diversification and Financial Performance of Commercial Banks in Kenya?. SEISENSE Journal of Management, 3(2), 14-30.

Ongore, V. O., \& Kusa, G. B. (2013). Determinants of financial performance of commercial banks in Kenya. International Journal of Economics and Financial Issues, 3(1), 237-252.

Patrick, H. T. (1996). Financial Development and Economic Growth in Underdeveloped Countries. Economic Development and Cultural Change, 14, 174-189.

Petria, N., Capraru, B., \& Ihnatov, I. (2015). Determinants of banks' profitability: Evidence from EU 27 banking systems. Procedia Economics and Finance, 20(15), 518-524. https://doi.org/10.1016/S2212-5671(15)00104-5

Pulic, A. (2008). The principles of intellectual capital efficiency-A brief description. Croatian Intellectual Capital Center, Zagreb, 76.

Robin, I., Salim, R., \& Bloch, H. (2018). Financial performance of commercial banks in the post-reform era: Further evidence from Bangladesh. Economic Analysis and Policy, 58, 43-54. https://doi.org/10.1016/j.eap.2018.01.001 
Saif-Alyousfi, A. Y., Saha, A., \& Md-Rus, R. (2017). The profitability of Saudi commercial banks: A comparative evaluation between domestic and foreign banks using CAMEL parameters. International Journal of Economics and Financial Issues, 7(2), 477-484.

Seref, T. (1995). Performance and Risk Analysis of the Islamic Banks: The Case of Bahrain Islamic Bank. Journal of Islamic Economics, 7, 3-13.

Shaari, A. H., \& Fadhilah, A. (2001). Performance Evaluation of Islamic Banking Scheme in Malaysia. Banker's Journal Malaysia, 118, 19-23.

Shabani, H., Morina, F., \& Misiri, V. (2019). The Effect of Capital Adequacy on Returns of Assets of Commercial Banks in Kosovo. European Journal of Sustainable Development, 8(2), 201-201. https://doi.org/10.14207/ejsd.2019.v8n2p201

Singh, A., \& Sharma, A. K. (2016). An empirical analysis of macroeconomic and bank-specific factors affecting liquidity of Indian banks. Future Business Journal, 2(1), 40-53. https://doi.org/10.1016/j.fbj.2016.01.001

Sporta, F. (2018). The Distressing Effect of Financial Performance on Capital Adequacy of Commercial Banks in Kenya. Journal of Resources Development and Management, 41, 28-36.

Sufian, F., \& Habibullah, M. H. (2009). Determinants of banks profitability in a developing economy: Empirical evidence from Bangladesh. Journal of Business Economics and Management, 10(3), 207-217. https://doi.org/10.3846/1611-1699.2009.10.207-217

Tan, Y. (2016). The impacts of risk and competition on bank profitability in China. Journal of International Financial Markets, Institutions \& Money, 40, 85-110. https://doi.org/10.1016/j.intfin.2015.09.003

Tan, Y., \& Floros, C. (2012). Bank profitability and inflation: The case of China. Journal of Economic Studies, 39(6), 675-696. https://doi.org/10.1108/01443581211274610

Veni, P. (2004). Capital Adequacy Requirement of Commercial Banks: A Study in Indian Context. GITAM Journal of Management, 2(2), 99-107.

Yahya, A. T., Akhtar, A., \& Tabash, M. I. (2017). The impact of political instability, macroeconomic and bank-specific factors on the profitability of Islamic banks: An empirical evidence. Investment Management and Financial Innovations, 14(4), 30-39. https://doi:10.21511/imfi.14(4).2017.04

Zardkoohi, A., \& Kolari, J. (1994). Branch office economies of scale and scope: Evidence from saving banks in Finland. Journal of Banking and Finance, 18(3), 421-432. Retrieved from http://www.sciencedirect.com/science/article/pii/0378-4266(94)90001-9

\section{Copyrights}

Copyright for this article is retained by the author(s), with first publication rights granted to the journal.

This is an open-access article distributed under the terms and conditions of the Creative Commons Attribution license (http://creativecommons.org/licenses/by/4.0/). 